\title{
In situ visualisation of immunoglobulin genes in normal and malignant lymphoid cells
}

\author{
C Carvalho, $M$ Telhada, $M$ do Carmo-Fonseca, L Parreira
}

\begin{abstract}
Aims-To directly visualise immunoglobulin (Ig) heavy (H) and light chain genes ( $\kappa$ and $\lambda$ ) in metaphase chromosomes and interphase nuclei of normal and malignant lymphocytes using small genomic probes targeted to intragenic sequences.

Methods-Cytogenetic preparations from phytohaemagglutinin stimulated lymphocytes, B-chronic lymphocytic leukaemia (B-CLL) cells, and a B-prolymphocytic leukaemia (B-PLL) cell line, containing a $t(11 ; 14)$, were hybridised in situ using biotin or digoxigenin labelled plasmid probes. The $\kappa$ genes were visualised with a combination of probes for the $\mathrm{C \kappa}, \mathrm{J} \kappa, \mathrm{V} \kappa 1$, and $V \kappa 2$ segments, the $\lambda$ genes with a probe containing the $\mathrm{J} \lambda 2-\mathrm{C} \lambda 2, \mathrm{~J} \lambda 3-\mathrm{C} \lambda 3$ segments and the $H$ genes with a probe for $C \gamma 2$. Hybridisation sites were visualised using appropriate fluorochrome conjugates and images were analysed by digital microscopy.
\end{abstract}

Results-In both normal and malignant lymphoid cells, the $\kappa$ and $\lambda$ genes were visualised as a single dot signal, whereas the $\mathbf{H} \gamma$ genes were resolved as either two or three separate signals per chromatid in metaphase chromosomes or per allele in interphase nuclei. In the malignant PLL cells, double hybridisation experiments with a painting library specific for the chromosome 11 showed that the $\gamma$ region was retained in the translocated chromosome, with an in situ resolution pattern similar to that of the normal allele.

Conclusions-This study shows that a high resolution in situ analysis of the three Ig loci can be efficiently performed with small size genomic probes on both normal and malignant lymphoid cells. Such an approach offers a flexible tool for the molecular characterisations of these loci on chromosomes and individual neoplastic cells.

(f Clin Pathol: Mol Pathol 1995;48:M158-M164)

Instituto de Histologia e Embriologia, Faculdade de

Medicina de Lisboa,

Av. Prof Egas Moniz, 1600 Lisbon, Portugal C Carvalho $M$ Telhada M do Carmo-Fonseca L Parreira

Correspondence to: Dr Leonor Parreira

Accepted for publication 20 December 1994 the $\mathrm{q} 32$ region of chromosome $14,{ }^{1} \mathrm{~K}$ genes on chromosome $2 \mathrm{p} 12$, and $\lambda$ genes on chromosome 22q11.2 During B cell differentiation Ig genes undergo an orderly series of re- mammalian cells immunoglobulin (Ig) (H) and light chains ( $\kappa$ and $\lambda$ ) are encode three unlinked loci, each mapped to separ arrangements which culminate in a productive transcriptional activity. In this process, previously independent $\mathrm{V}, \mathrm{J}$, and $\mathrm{D}(\mathrm{H})$ segments are brought together through the deletion of intervening DNA sequences. The discovery that a wide variety of different VJ or VDJ complexes can be originated through simple combinative options has elegantly clarified the genetic basis of antibody diversity. ${ }^{3}$

Since Ig gene rearrangements are a prerequisite for the synthesis of immunoglobulin molecules and at the same time consist of irreversible DNA modifications in each individual cell, they have been considered as both B cell lineage specific phenomena and reliable markers of clonality. Furthermore, Ig loci are frequently involved in the breakpoints of reciprocal chromosomal translocations found in $\mathrm{B}$ cell malignancies, a fact that may be related to the transient genomic unstability underlying V(D)J rearrangements. ${ }^{4}$ For all these reasons, the structural analysis of these genes soon extended beyond the more fundamental fields of basic immunology, to be extensively exploited in the characterisation of haematological malignancies (reviewed in ${ }^{5}$ ). So far these studies have relied mostly upon biochemical methods, such as Southern blot analysis of total genomic DNA, which fail to give information on the physical status of the gene at the single cell level. The high resolution visualisation of specific DNA sequences, in both nuclei and metaphase chromosomes, can now be accomplished by the recently developed methods of fluorescent hybridisation and digital image processing. ${ }^{6-8}$ Although as yet very little information is available concerning the in situ analysis of Ig genes, the potential of these new approaches has recently been illustrated in the work by Joos et al, ${ }^{9}$ where in situ hybridisation helped to characterise the breakpoints of $\mathrm{IgH} /$ c-myc translocations in Burkitt lymphoma cell lines. The latter study, as in most aimed at the in situ analysis of single copy genes, relied on the use of probes covering large genomic regions. However, any attempt at direct visualisation of Ig genes in B cell populations must take into account the deletion events which take place in these genes during somatic rearrangement. In this perspective, the possibility of detecting small intragenic sequences within each Ig locus is likely to add further flexibility to a more generalised in situ analysis of Ig genes in malignant $\mathrm{B}$ cell disorders.

In this study we have sought to visualise directly the IgH and light chain genes in metaphase chromosomes and interphase nuclei of normal and malignant lymphocytes. To do this we have made use of selected small genomic 
probes specific to different intragenic regions in each locus, which were hybridised in situ and detected by digital fluorescence microscopy.

\section{Methods}

CELLS

Human peripheral blood lymphocytes obtained from healthy donors, a fresh peripheral blood sample from an IgM-k expressing B-chronic lymphocytic leukaemia (B-CLL), and a human cell line derived from a patient with B-prolymphocytic leukaemia (JVM-2) were used in this study. The phenotype and genotype of the JVM-2 cell line have been fully characterised by Melo et al. ${ }^{1011}$ Briefly, JVM-2 cells are IgM- $\lambda$ expressing cells containing a $t(11$; 14)(q13;q32); the Ig genotype consists of a biallèlic $\mathrm{JH}$ rearrangement, germ line configuration at both $\kappa$ alleles, and rearrangement of one $\lambda$ allele, the other remaining in germ line configuration. ${ }^{10}$ The breakpoint on the $\mathrm{t}(11 ; 14)$ has been shown to map at the $\mathrm{J} 4$ region in the $\mathrm{H}$ chain gene. ${ }^{12}$

Metaphase spreads from phytohaemagglutinin (PHA; Wellcome) stimulated peripheral blood lymphocytes and from a 48 hour culture of the JVM-2 cell line were produced by standard cytogenetic methods. Mononuclear cells from the B-CLL sample were isolated by density gradient centrifugation in Lymphoprep (Nycomed) and submitted, without stimulation, to the same hypotonic and fixative procedures as for cytogenetic preparations.

The slides were air dried at room temperature, dehydrated in an ethanol series $(70 \%$, $90 \%, 100 \%)$, and stored desiccated at room temperature for short term use, or at $-70^{\circ} \mathrm{C}$ for longer periods.

\section{PROBES}

Chromosomes 2, 11, 14, and 22

Painting probes specific to chromosomes 2, 11, and 22 (biotin labelled) and 14 (FITC labelled) were purchased from Cambio. Due to cross hybridisation problems, the chromosome 22 library was hybridised in the presence of $0.7-2 \mathrm{mg} / \mathrm{ml}$ of dried human Cot 1 DNA (Gibco-BRL).

\section{Ig heavy chain genes}

The probe for $\mathrm{C} \gamma 2$ was a $1.8 \mathrm{~kb}$ Pst I genomic insert cloned in pBR322, containing the $\mathrm{CH} 3$ and $\mathrm{CH} 2$ segments of the $\mathrm{C} \gamma 2$ constant regions, ${ }^{13}$ which also recognises the $\mathrm{C} \gamma 1, \mathrm{C} \gamma 3$, and $\mathrm{C} \gamma 4$ segments and a pseudo $\gamma$ gene located between $C \alpha 1$ and $C \gamma 2 .^{1415}$

\section{Ig $\kappa$ chain genes}

The $\kappa$ genes were visualised using a combination of the following probes: $\mathrm{Ck}$, a SacI $0.6 \mathrm{~kb}$ genomic fragment cloned in pBR322, containing the $\mathrm{k}$ constant region ${ }^{16} ; \mathrm{JK}$, a $5 \mathrm{~kb}$ HindIII genomic fragment cloned in pUC12 containing all five $\kappa \mathrm{J}$ segments; $V \kappa 1$, a $0.2 \mathrm{~kb}$ PstI genomic insert cloned in pGEM hybridising to $\mathrm{V} \kappa 1$ family of segments; $\mathrm{V} \kappa 2$, a $0 \cdot 2 \mathrm{~kb} \mathrm{BamHI} / S p h \mathrm{I}$ genomic fragment cloned in pUC19, hybridising to the Vк2 segments.

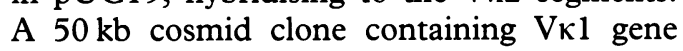
segements (5b) was also used in some experiments (see Results).

Ig $\lambda$ chain genes

The $C \lambda$ probe was a EcoRI-HindIII $7.5 \mathrm{~kb}$ genomic insert cloned in pUC19, containing $\mathrm{J} \lambda 2, \mathrm{C} \lambda 2, \mathrm{~J} \lambda 3$, and $\mathrm{C} \lambda 3$, which hybridised to all other $\mathrm{C} \lambda$ segments. ${ }^{17-20}$

\section{IN SITU HYBRIDISATION}

The probes for Ig genes were labelled with biotin (16)-deoxyuridine triphosphate or digoxigenin (11)-deoxyuridine triphosphate (Boehringer Manheim) by nick translation, as described by Johnson et $a l,{ }^{21}$ and purified through G50 Sephadex columns. Probe sizes between 200 and 500 nucleotides, as assessed by electrophoresis in $1 \%$ agarose gel, were used. ${ }^{22}$ Defined quantities of probe $(4 \mu \mathrm{l} / \mathrm{ml}$ of hybridisation mixture) were combined with sonicated herring sperm DNA $(0.3 \mathrm{mg} / \mathrm{ml})$ (Sigma) and human Cot 1 DNA $(0.7 \mathrm{mg} / \mathrm{ml})$ (Gibco-BRL), ethanol precipitated, air dried, and dissolved in hybridisation buffer $(50 \%$ formamide, $2 \times \mathrm{SSC}(\mathrm{NaCl} /$ sodium citrate), $10 \%$ dextran sulphate, $50 \mathrm{mM}$ phosphate buffer, $\mathrm{pH} 7 \cdot 0$ ). Probes in hybridisation buffer were stored at $-20^{\circ} \mathrm{C}$ until use.

Before hybridisation, the slides were rehydrated in $2 \times \mathrm{SSC}$, incubated in RNase A $(0.1 \mathrm{mg} / \mathrm{ml}$ in $2 \times \mathrm{SSC})$ at $37^{\circ} \mathrm{C}$ for one hour and washed in $2 \times \operatorname{SSC}(3 \times 5 \mathrm{~min})$, followed by incubation in pepsin/ $\mathrm{HCl} 10 \mathrm{mM}(50 \mu \mathrm{g} / \mathrm{ml}$ in the case of PHA stimulated lymphocytes and JVM-2 cells, $200 \mu \mathrm{g} / \mathrm{ml}$ for B-CLL cells) at $37^{\circ} \mathrm{C}$ for 10 minutes. The slides were then washed in phosphate buffered saline (PBS; $2 \times 5 \mathrm{~min}), \mathrm{PBS} / \mathrm{MgCl}_{2} 50 \mathrm{mM}(1 \times 5 \mathrm{~min})$, fixed in formaldehyde $1 \%$ for 10 minutes, washed again in PBS $(3 \times 5 \mathrm{~min})$, and dehydrated in an ethanol series.

Sample denaturation was performed by incubating the slides in $70 \%$ formamide, $2 \times \mathrm{SSC}$, at $70^{\circ} \mathrm{C}$ for two minutes, followed by dehydration in a series of ice cold ethanol $(70,90,100 \%, 3$ minutes each). Probes were denatured by heating at $70^{\circ} \mathrm{C}$ for 10 minutes, followed by incubation for 10 to 60 minutes at $37^{\circ} \mathrm{C}$, to promote the annealing of human Cot 1 DNA to repetitive sequences. ${ }^{22}$ After preannealing, $3 \mu \mathrm{l}$ of probe were applied onto the slide and spread under a $18 \times 18 \mathrm{~mm}$ coverslip, subsequently sealed with rubber cement, and incubated for at least 16 hours at $37^{\circ} \mathrm{C}$.

After hybridisation the slides were washed in $50 \%$ formamide, $2 \times \mathrm{SSC}$ at $45^{\circ} \mathrm{C}(3 \times 5 \mathrm{~min})$, and $0 \cdot 1 \times \mathrm{SSC}$ at $60^{\circ} \mathrm{C}(3 \times 5 \mathrm{~min})$.

Detection was done by immunofluorescence methods with an amplification step. Biotinylated probes were detected by sequential incubations with FITC or Texas Red conjugated avidin $(5 \mu \mathrm{g} / \mathrm{ml})$, biotinylated anti-avidin antibody $(5 \mu \mathrm{g} / \mathrm{ml})$, and FITC or Texas Red conjugated avidin $(5 \mu \mathrm{g} / \mathrm{ml}$ ) (all purchased from Vector Laboratories). Detection of digoxigenin labelled probes was done with antidigoxigenin mouse antibody $(0.4 \mu \mathrm{g} / \mathrm{ml})$ fol- 
lowed by digoxigenin conjugated rabbit antimouse antibody $(2 \mu \mathrm{g} / \mathrm{ml})$ and FITC or TRITC conjugated anti-digoxigenin antibody $(2 \mu \mathrm{g} / \mathrm{ml})$ (Boehringer Manheim). The signal from painting probes directly labelled with FITC was amplified with anti-FITC rabbit antibody $(70 \mu \mathrm{g} / \mathrm{ml}$ ) (Dako Patts) followed by FITC conjugated anti-rabbit antibody $(40 \mu \mathrm{g} / \mathrm{ml})$ (Sigma). The detection components were diluted in $4 \times$ SSC, $0 \cdot 1 \%$ Tween $20,1 \%$ BSA (Sigma) (ST), and incubations were performed at $37^{\circ} \mathrm{C}$ for 30 minutes. Washing steps between incubations were done in ST at $37^{\circ} \mathrm{C}$ $(3 \times 5 \mathrm{~min})$. After the last washing, the slides were rinsed in $2 \times$ SSC, dehydrated through an ethanol series, air dried, and mounted in Vectashield antifading mounting medium (Vector) containing the DNA counterstain DAPI (diaminophenylindol) $20 \mathrm{ng} / \mathrm{ml}$ or PI (propidium iodide) $500 \mathrm{ng} / \mathrm{ml}$.

\section{DIGITAL IMAGE ANALYSIS}

Fluorescence microscopy was performed using the Zeiss laser scanning microscope 310 equipped with a SIT Camera and the Argus 10 image processor (Hamamatsu, Japan). All images were acquired using a $100 \times$ magnification oil objective. For double and triple labelling experiments, images from each fluorochrome were sequentially recorded in the same focal plane, and pseudo-colour images were generated and superimposed.

\section{Results}

VISUALISATION OF CHROMOSOMES 2, 14, AND 22 IN NORMAL METAPHASE CHROMOSOMES AND INTERPHASE NUCLEI

In order to identify specifically each of the chromosomes where the Ig genes are located, painting probes for chromosomes 2, 14, and 22 were used. In metaphase chromosomes the genomic libraries specific to chromosomes 2 and 14 generally produced specific signals, whereas the probe for chromosome 22 revealed significant cross hybridisation with other genomic sequences in all preparations. The cross signal was predominantly seen on the short arms of other acrocentric chromosomes, a finding that can be explained by the presence of the structurally homologous ribosomal genes in the nucleolar organisers of these chromosomes. This problem of cross hybridisation was minimised by adding competitor human Cot1 DNA to the hybridisation mixture.

In interphase nuclei, each individual chromosome probe labelled two discrete domains within the nucleoplasm. The size and shape of each specific signal were markedly variable within the same preparation.

VISUALISATION OF IMMUNOGLOBULIN GENES IN NORMAL METAPHASE CHROMOSOMES AND INTERPHASE NUCLEI

Having established the conditions for specific labelling of chromosomes 2,14 , and 22 , we subsequently proceeded to the detection of $\mathrm{Ig}$ genes at the chromosomal and nuclear levels.
A $50 \mathrm{~kb}$ cosmid clone specific to the Vk1 gene segments was used in the first experiments. As illustrated in fig $1 \mathrm{~A}, \mathrm{D}$, although the probe has efficiently detected the $\kappa$ locus at the expected region of the chromosome 2 , a significant cross hybridisation was found both on metaphase chromosomes and in interphase nuclei. To overcome this limitation, plasmid probes containing genomic regions present in the $\kappa$ locus were subsequently used. These consisted of a mixture of four genomic clones: a $0.6 \mathrm{~kb}$ fragment containing the $\mathrm{C} \kappa$ region, a $5 \mathrm{~kb}$ fragment encompassing the $5 \mathrm{JK}$ segments, and two $0.2 \mathrm{~kb}$ inserts hybridising to $\mathrm{V}$ segments belonging to the $V \kappa 1$ and $V \kappa 2$ families. As shown in fig $1 \mathrm{~B}$, the mixed probe hybridised to both chromatids at the expected region on the short arm of chromosome 2, without cross hybridisation to other chromosomal regions. In the majority of interphase nuclei two clean single dot signals were detectable as shown in fig $1 \mathrm{E}$. Similar results were obtained with the $7.5 \mathrm{~kb} \mathrm{C} \lambda$ probe, both in metaphase chromosomes and in interphase nuclei (fig $1 \mathrm{C}, \mathrm{F}$ ). This probe also recognises the other $C \lambda$ regions in the locus, as well as pseudo- $\lambda$ gene sequences located in other chromosomes. ${ }^{23}$ In some nuclei, the latter originated additional signals of significantly lower intensity. In other nuclei two closely spaced paired signals, instead of one, could be seen at one or both $\kappa$ and $\lambda$ allelles, suggesting that DNA replication had already taken place in those cells.

The heavy chain genes were visualised with a $1.8 \mathrm{~kb}$ single probe containing the $\mathrm{C} \gamma 2$ region. In double hybridisation experiments with the chromosome 14 library, $\mathrm{C} \gamma 2$ hybridised to the expected region on the telomere of chromosome 14 (data not shown). This probe is known to cross hybridise with three other functional $\gamma$ genes and also with a pseudo- $\gamma$ segment. ${ }^{13}$ In the majority of metaphase chromosomes, two distinct but closely spaced signals of different intensities were visible along the length or the width of each chromatid (fig 1G). Occasionally, three signals could be detected in one chromatid (fig $1 \mathrm{H}$ ). In interphase nuclei, each allele was visualised as two or three closely spaced signals, again with different intensities (fig $1 \mathrm{I}, \mathrm{J}$ ). The variation in the number and intensity of signals within the same preparation is possibly related to different degrees of chromatin condensation, a factor known to have a major influence in the resolution of signals originated by probes recognising distinct sequences within the same genomic region. ${ }^{22} 24$

\section{VISUALISATION OF IMMUNOGLOBULIN GENES IN} B-CLL CELLS AND JVM-2 CELL LINE

To investigate whether these probes could efficiently detect the three Ig loci in malignant $B$ cells, similar experiments were performed in the JVM-2 cell line and in unstimulated peripheral blood B-CLL cells. In JVM-2 cells, all loci were easily detected in the same experimental conditions as PHA stimulated lymphocytes. In interphase nuclei, the resolution patterns for both the $\kappa$ and $\gamma$ loci turned out to 

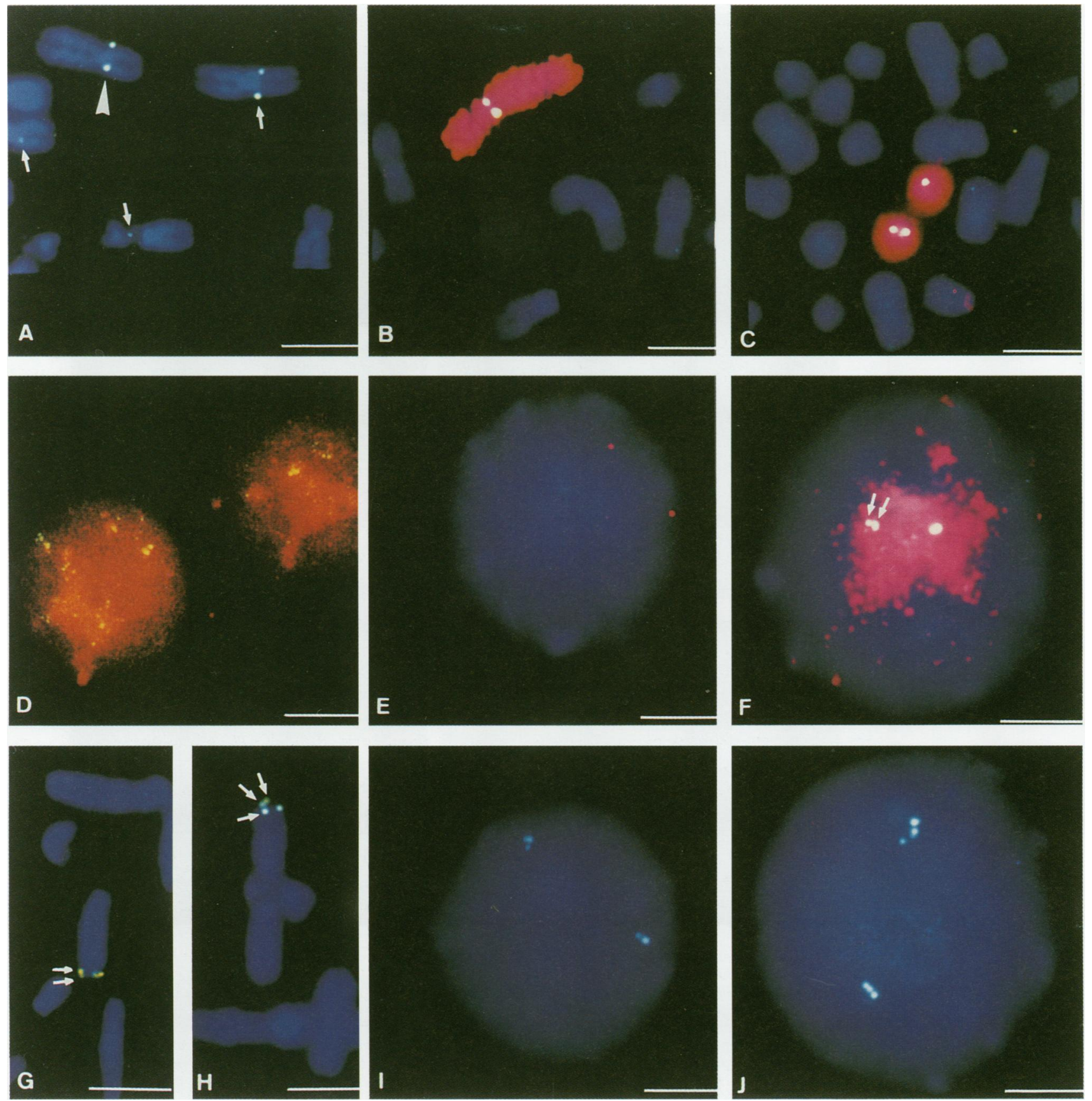

Figure 1 Visualisation of Ig genes by fluorescence in situ hybridisation in phytohaemagglutinin stimulated lymphocytes. (A) Metaphase chromosomes were labelled with the DNA stain DAPI (blue) and hybridised with a cosmid probe containing VK1 segments (green): arrowhead indicates hybridisation signal on the short arm of chromosome 2 and arrows point to cross hybridisation with VK genes in other chromosomes. (B) Triple labelling of metaphase chromosomes with DAPI (blue), a painting library for chromosome 2 (red), and a mixture of plasmid probes containing VK, $\mathcal{F}$, and $C \kappa$ segments (green; note that the white colour is due to superimposition of blue, red, and green staining). (C) Triple labelling of metaphase chromosomes with DAPI (blue), a painting library for chromosome 22 (red) and a plasmid Ch probe (green). Note the variation in the number of signals observed in the same preparation, which may be due to different degrees of chromatin condensation. 24 (D) Interphase nuclei were labelled with propidium iodide (red) and hybridised with the VK1 cosmid probe (green; note that the yellow signals are due to superimposition of red and green staining). (E) Interphase nucleus stained with DAPI (blue) and hybridised with $\kappa$ plasmid probes (red). (F) Triple labelling for interphase nucleus with DAPI (blue), a painting library for chromosome 22 (red), and a plasmid Ci probe (green). Note that in one allele the signal appears as a doublet (arrows). (G-H) Metaphase chromosomes labelled with DAPI (blue) and hybridised with the C 2 probe (green): arrows indicate two or three signals orientated either across the length or across the width of the chromatids. (I-7) Interphase nuclei stained with DAPI (blue) and hybridised with the C 2 probe (green). Bar corresponds to either $5 \mu m(A-C, E-\mathcal{F})$ or $10 \mu m(D)$.

be essentially similar to those described above. However, the two $\mathrm{C} \lambda$ alleles were consistently visualised as single dot signals of different sizes and intensity (fig $2 \mathrm{~A}$ ). As the JVM-2 cell line has a $11 ; 14$ chromosomal translocation involving the $\operatorname{IgH~} \mathrm{J}$ region, we further asked whether the proximity of an alien chromatin piece would alter the in situ resolution of the $\gamma$ locus in the translocated chromosome. Thus a double hybridisation experiment with a chro- mosome 11 library was performed, in order to identify the translocated allele unequivocally. As shown in fig $2 \mathrm{~B}, \mathrm{C}$, the $\mathrm{C} \gamma 2$ probe originated similar patterns of resolution on both the normal and the translocated chromosome, a finding suggesting that the $\gamma$ region is likely to remain physically intact in the translocated allele.

In the experiments on B-CLL cells, higher concentrations of pepsin in the prehybrid- 

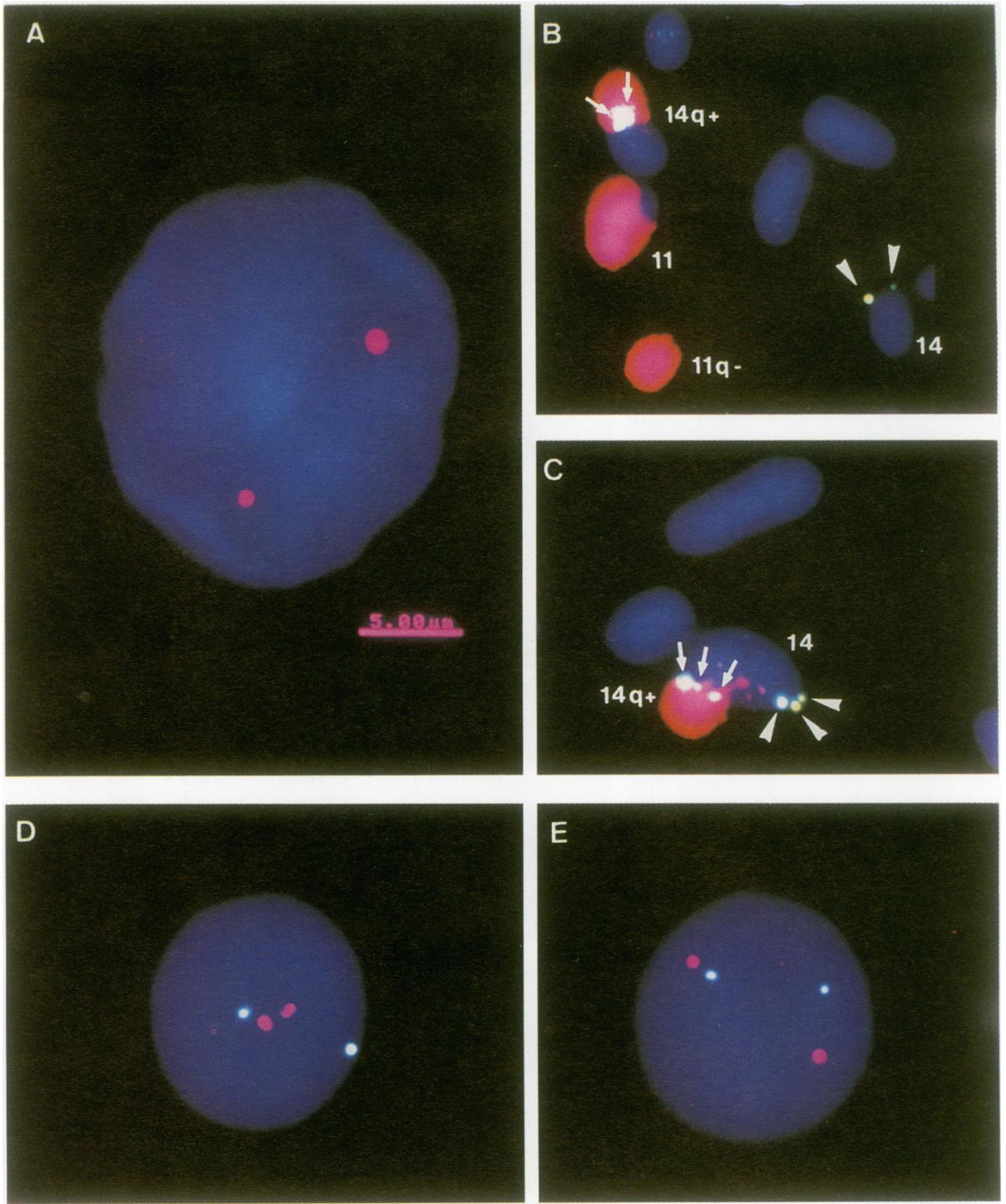

Figure 2 Visualisation of Ig genes by fluorescence in situ hybridisation in malignant B cells. (A) Interphase nucleus from the $\mathcal{F} V M-2$ cell line stained with DAPI (blue) hybridised with the $C i$ probe (red). Note that each $i$ allele originated signals of different sizes (see text). $(B-C)$ Insets of metaphase plates from the $\mathcal{F V M - 2}$ cell line triple labelled with DAPI (blue), a painting library for chromosome 11 (red), and the $C^{*} 2$ probe (green). The hybridisation signals originated by the C $C$ probe on the normal chromosome 14 are indicated by arrowheads and by arrows on the 11;14 originated by the $C ;$; probe on the normal chromosome 14 are indicated by arrowheads and by arrows on the $11 ; 14$
translocated chromosome. In (B) are also shown the normal chromosome 11 as well as the $11 q-;$ note that in $(C)$ both the normal and the translocated chromosomes 14 are associated through their short arms. (D-E) Interphase nuclei from $B-C L L$ stained with DAPI (blue), double hybridised with the $C^{\prime} 2$ (green) and Ci probes (red) in (D), and with C 2 (green) and $\kappa$ probes (red) in (E). Bar $=5 \mu \mathrm{m}$.

isation treatment were found to be necessary in order to optimise the signal intensity with all probes (see Methods). This is likely to reflect problems in probe accessibility originated by the highly compacted chromatin of B-CLL cells. Nonetheless, in the conditions used in this study, the three loci could easily be detected in the majority of interphase nuclei, with resolution patterns that were essentially similar to those of PHA stimulated lymphocytes (fig $2 \mathrm{D}$, E). In a more general perspective, these observations are likely to be relevant for studies

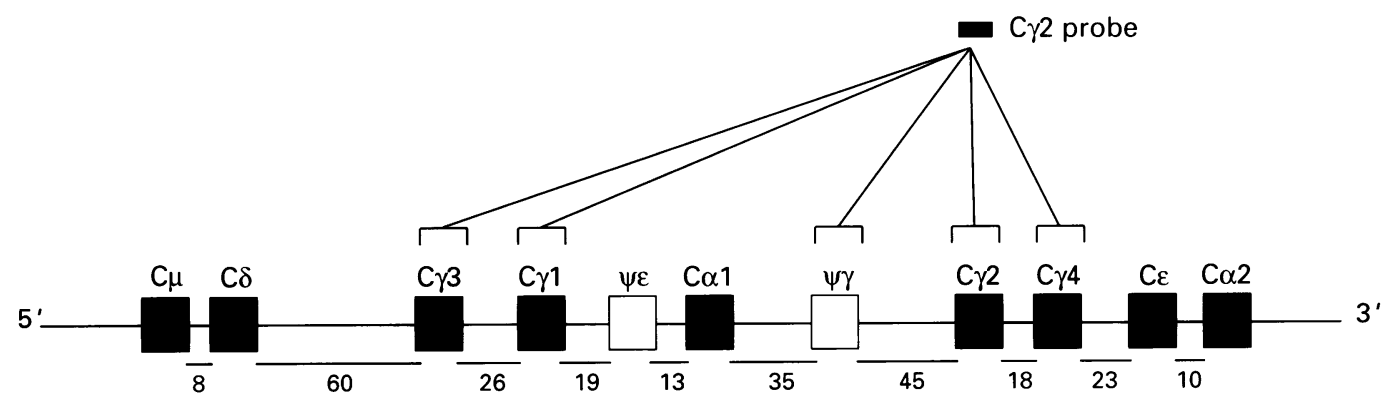

Figure 3 Diagram representing the organisation of the human IgH constant genes on chromosome 14 (not on scale). The intragenic regions recognised by the $C 2$ probe used in this study are indicated (see text for details). The distances between the $C$ regions are in $k b$, and are based on published data. ${ }^{131531.33}$ 
aimed at visualising $\mathrm{Ig}$ genes in other chronic lymphoproliferative disorders, such as nonHodgkin lymphomas and hairy cell leukaemia, in which the malignant cell nucleus also shows highly condensed chromatin patterns.

\section{Discussion}

In this study we have visualised the Ig heavy and light chain genes in both interphase nuclei and metaphase chromosomes of normal and malignant lymphoid cells.

In relation to the detection of Ig genes, it is necessary to take into account the structural modifications that these genes suffer in B lymphoid cells as a consequence of somatic recombination. ${ }^{3}$ To overcome this problem the establishment of all technical conditions was deliberately carried out in lymphoid cells stimulated with PHA. This mitogen predominantly stimulates the proliferation of $T$ lymphoid cells $^{25}$ where the Ig genes are likely to be in germ line configuration. A further criterion was that the probes covered, as much as possible, regions with a high probability of remaining in the locus after recombination, so that the analysis could later be extended to B cell populations.

In order to control the hybridisation specificity of each Ig probe, the optimal conditions for the detection of chromosomes 2, 14, and 22 were first established in metaphase plates from PHA stimulated human peripheral blood lymphocytes. The hybridisation signal produced by each Ig probe was then tested by double colour hybridisations with the respective chromosome painting library. As it is generally believed that probes larger than $10 \mathrm{~kb}$ have a higher efficiency in detecting single copy sequences, ${ }^{924}$ a $50 \mathrm{~kb}$ cosmid clone specific to Vк1 segments was used in the first experiments. Although highly successful in detecting the $\kappa$ gene at the 2 p12 region, this probe proved to be useless for further interphase analysis as it also hybridised with pseudo-VK genes present in several other chromosomes. ${ }^{26}$ Thus we decided to use a different strategy: collections of independent plasmid clones or single clones targeting different intragenic sequences were used. All the selected probes caused the origination, in metaphase plates, of signals that were exclusively located at the expected chromosomal region and as such were considered suitable for interphase analysis in these cells.

The hybridisation patterns for each of the plasmid probes can be summarised as follows: signals obtained with the $\mathrm{C} \lambda$ and the $\mathrm{C} \kappa-\mathrm{J} \kappa-$ VK probes consistently emerged as two single dots in interphase cells and as one dot per chromatid in metaphase chromosomes. This was somewhat expected considering the germ line structure of these regions. In fact, the $C \lambda$ probe also hybridises with other $\mathrm{C} \lambda$ segments, which together span $50 \mathrm{~kb}$ at the $\lambda$ locus and are separated from each other by approximately $10 \mathrm{~kb} .^{1823}$ These linear inter-region distances are below the lower limit of resolution of fluorescence microscopy, which apparently does not resolve sequences separated by less than $25 \mathrm{~kb} .{ }^{27}$ As far as the $\kappa$ genes are concerned,

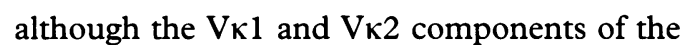
mixed probe are known to cross hybridise to pseudo-genes in other chromosomes, ${ }^{1626}$ no evidence for cross hybridisation outside the $\kappa$ locus was found in either interphase or metaphase chromosomes. Possibly, in these experimental conditions, the signals originated by pseudo-genes were too faint to be detectable. Experiments where the $V \kappa$ probes $(0.2 \mathrm{~kb}$ fragments) were used alone support this assumption, as the signals were hardly visible in only a few metaphase chromosomes. Accordingly, it can be concluded that the visualisation of the $\kappa$ genes was mainly accomplished by the $\mathrm{J} \kappa$ and $\mathrm{C} \kappa$ probes which recognise two regions separated from each other by only $2 \cdot 4 \mathrm{~kb} .^{28}$

In contrast with the results described above, hybridisation with the $\mathrm{H}$ gene $\mathrm{C} \gamma 2$ probe showed a different labelling pattern. In the majority of metaphase chromosomes, two distinct signals of different intensities were visible either across the length or across the width of each chromatid. Occasionally, three signals were resolved per chromatid. Considering the linear DNA distances between the $\mathrm{C} \gamma$ segments recognised by this probe (see the diagram in fig 3 ), the expected hybridisation pattern should consist of three separate signals, the first originated by the $\mathrm{C} \gamma 3-\mathrm{C} \gamma \mathrm{l}$ segments $(26 \mathrm{~kb}$ apart), the second by the $\mathrm{C} \gamma 2-\mathrm{C} \gamma 4$ segments (separated by $18 \mathrm{~kb}$ ), and the third by the pseudo- $\mathrm{C} \gamma$ gene, which is located approximately $70 \mathrm{~kb}$ downstream to $\mathrm{C} \gamma 1$ and $45 \mathrm{~kb}$ upstream to $\mathrm{C} \gamma 2 .{ }^{1315}$ It is conceivable that doublets are caused by coalescence of signals originated by the pseudo-C $\gamma$ and one of the functional $\mathrm{C} \gamma$ clusters. This would further explain the asymmetry in signal intensity among the partners of each doublet. In interphase nuclei, each $\mathrm{C} \gamma$ allele was also seen as either two or three separate signals, consistent with the results obtained in metaphase chromosomes.

The results obtained in B-CLL cells and in the prolymphocytic cell line clearly showed that these probes were also efficient in detecting the Ig genes in these two different malignant B cell populations. The extrapolation of the present results for a more general in situ analysis of Ig genes in B cells deserves, however, a few comments. It is theoretically conceivable that the efficiency of each probe in visualising the respective locus may vary among different $B$ cell populations, as Ig genes are structurally modified in these cells. In relation to the mixed $\kappa$ probes, as the constant region is always represented in recombined $\kappa$ genes, ${ }^{3}$ and the $\mathrm{J} \kappa$ component of the probe contains all the germline $\mathrm{J} \kappa$ segments, the $\mathrm{C} \kappa-\mathrm{J} \kappa$ combination is likely to be useful for the study of most B lymphoid cells. This assumption cannot, however, be safely generalised for the other probes, particularly for $\mathrm{C} \lambda$. The germ line organisation of $\lambda$ genes differs from those of $\mathrm{H}$ and $\kappa$ genes in that each constant segment is preceded by a J segment. ${ }^{171820}$ Hence the particular recombination event that took place in each cell will certainly influence the signal intensity between different samples or even between the 
two homologous loci within the same cell. The patterns of $\mathrm{C} \lambda$ hybridisation in the JVM- 2 cells support this assumption, as the two $\lambda$ alleles were consistently visualised as signals of different sizes and intensity, consistent with the fact that one $\lambda$ allele is in germ line configuration, whereas the other has undergone somatic rearrangement. ${ }^{10} \mathrm{~A}$ similar phenomenon can be anticipated with regard to the $\gamma$ locus, as the deletion of target sequences can also occur in mature $B$ cells that have progressed to heavy chain class switch. ${ }^{29} 30$ This was not the case in the malignant cells analysed in this study which, as IgM expressing cells, are likely to retain the $\mathrm{C} \gamma$ segments in germ line configuration. The double hybridisation experiments with the chromosome 11 painting library, performed in JVM-2 cells, showed that the $\gamma$ region is retained and probably undisturbed in the translocated chromosome 14. These findings illustrate the value of simultaneously visualising single copy genes and whole chromosomes as a tool for the fine characterisation of gene/ chromosomal aberrances in neoplastic cells.

In conclusion, the present study shows that a high resolution visualisation of Ig genes within individual cells or chromosomes can be accomplished with probes routinely used for Southern blot analysis. Such an approach is likely to add further flexibility to the in situ analysis of chromosomal rearrangements involving this complex genetic system in neoplastic lymphoid cells.

The authors are grateful to Dr T H Rabbitts (Laboratory of Molecular Biology, Cambridge) for providing DNA probes fo $\mathrm{HC} \%, \mathrm{C} \lambda$, and $\mathrm{C} \kappa$; to Professor L Luzzatto (Department of Haematology, Royal Postgraduate Medical School, Hammersmith Hospital, London) for JK and VK probes; and to D J V Melo (Royal Postgraduate Medical School, Hammersmith Hospital, London) for the JVM-2 cell line. This work was supported by a grant from Junta Nacional de Investigaço from Junta Nacional de Investigaça o JNICT fellowship.

1 Croce CM, Shander M, Martinis J, Cicurel L, D'Ancona GG, Dolby TW, et al. Chromosomal location of the genes for human immunoglobulin heavy chains. Proc Natl Acad Sci USA 1979;76:3416-9.

2 McBride OW, Hieter PA, Hollis GF, Swan D, Otey MC Leder P. Chromosomal location of human kappa lambda mmunoglobulin light chain constant regions genes. $\mathcal{F}$ Exp Med 1982;155:1480-90.

3 Tonegawa S. Somatic generation of antibody diversity. $\mathrm{Na}$ ture 1983;302:575-81.

4 Sawyers CL, Denny CT, Witte ON. Leukemia and the disruption of normal hematopoiesis. Cell 1991;64:337-50.

5 Korsmeyer SJ. Antigen receptor genes as molecular markers of lymphoid neoplasms. F Clin Invest 1987;79:1291-5.

6 Van Dekken H, Van Rotterdam A, Jonker R, Van der Voort HTM, Brakenhoff GJ, Bauman JG. Confocal microscopy as a tool for the study of the intranuclear topography of as a tool for the study of the intranuclear top

7 Lichter P, Boyle AL, Cremer T, Ward DC. Analysis of genes and chromosomes by nonisotopic in situ hybridization. Genet Anal Tech Appl 1991;8:24-35.

8 Trask BJ. Fluorescent in situ hybridization: applications in cytogenetics and gene mapping. Trends Genet 1991;7: $149-54$

9 Joos S, Falk MH, Lichter P, Haluska FG, Henglein B, Lenoir GM, et al. Variable breakpoints in Burkitt lymphoma cells with chromosomal $\mathrm{t}(8 ; 14)$ translocation separate $\mathrm{c}$-myc and the IgH locus up to several hundred kb. Hum Mol Genet 1992;1:625-32.

10 Melo JV, Brito-Babapulle V, Foroni L, Robinson DSF Luzzatto L, Catovsky D. Two new cell lines from Bprolymphocytic leukaemia: characterization by morphology, immunological markers, karyotype and Ig gene rearrangement. Int 7 Cancer 1986;38:531-8.

11 Melo JV, Foroni L, Brito-Babapulle V, Luzzatto L, Catovsky D. The establishment of cell lines from chronic B cell leukaemias: evidence of leukaemic origin by karyotypic abnormalities and Ig gene rearrangement. Clin Exp Immunol 1988;73:23-8

12 Rabbitts PH, Douglas J, Fischer P, Navecha E, Karpas A Catovsky D, et al. Chromosome abnormalities at "913 in B cell tumours. Oncogene 1988;3:99-103.

13 Krawinkel U, Rabbitts TH. Comparison of the hinge-coding segments in human immunoglobulin gamma heavy chain genes and the linkage of the gamma 2 and gamma 4 subclass genes. $E M B O \mathcal{f} 1982 ; 1: 403-7$.

14 Bottaro A, de Marchi M, Migone N, Carbonara AO. Pulsedfield gel analysis of human immunoglobulin heavy-chain constant region constant region gene deletions reveals the extent of un-
mapped regions within the locus. Genomics 1989;4:505-8.

mapped regions within the locus. Genomics $1989 ; 4: 505-8$.
15 Hofker $\mathrm{MH}$, Walter MA, Cox DW. Complete physical map of the human immunoglobulin heavy chain constant region complex. Proc Natl Acad Sci USA 1989;86:5567-71.

16 Bentley DL, Rabbitts TH. Evolution of immunoglobulin V genes: evidence indicating that recently duplicated human $\mathrm{V} \kappa$ sequences have diverged by gene conversion. Cell 1983; 32:181-9.

17 Taub RA, Hollis GF, Hieter PA, Korsmeyer S, Waldman TA, Leder P. Variable amplification of immunoglobulin $\lambda$ light-chain genes in human populations. Nature 1983;304: $172-4$

18 Hieter PA, Korsmeyer SJ, Waldman TA, Leder P. Human immunoglobulin $k$ light-chain genes are deleted or reimmunoglobulin $k$ light-chain genes are deleted or re-
arranged in $\lambda$-producing cells. Nature 1981;290:368-72.

19 Udey JA, Blomberg B. Human $\%$ light-chain locus: organization and DNA sequences of three genomic J regions. Immunogenetics 1987;25:63-70.

20 Dariavach $P$, Lefranc G, Lefranc M-P. Human immunoglobulin $\mathrm{C} \lambda 6$ gene encodes the $\mathrm{Kern}+\mathrm{Oz}-\lambda$ chain and $\mathrm{C} \lambda .4$ and $\mathrm{C} \lambda .5$ are pseudogenes. Proc Natl Acad $\mathrm{Scl}_{\mathrm{c}}$ USA 1987;84:9074-8.

21 Johnson CV, Singer RH, Lawrence JB. Fluorescent detection of nuclear RNA and DNA: implications for genome organization. Methods Cell Biol 1991;35:73-97.

22 Lichter P, Cremer T, Tang C-I, Hatkins PC, Manuelidis L, Ward DC. Delineation of individual human chromosomes in metaphase and interphase cells by in situ suppression hybridization using recombinant DNA libraries. Hum genet hybridization using

23 Chang H, Dmitrovsky E, Hieter PA, Mitchell K, Leder P, Turoczi $\mathrm{L}$, et al. Identification of three new Ig i-like genes in man. F Exp Med 1986;163:425-35.

24 Lichter P, Tang C-J C, Call K, Hermanson G, Evans GA Housman D, et al. High-resolution mapping of human chromosome 11 by in situ hybridization with cosmid clones. Science 1990;247:64-9.

25 Klaus GGB. Lymphocytes: a practical approach. Oxford: IRI Press, 1987.

26 Meindl A, Klobeck H-G, Ohnheiser R, Zachau HG. The VK gene repertoire in the human germ line. Eur 7 Immunol 1990;20:1855--63.

27 Lawrence JB, Singer RH, McNeil JA. Interphase and metaphase resolution of different distances within the human dystrophin gene. Science 1990;249:928-32.

28 Hieter PA, Max EE, Seidman JG, Maizel JV, Leder P. Cloned human and mouse $\kappa$ immunoglobulin constant and $\mathrm{J}$ region genes conserve homology in functional segments. Cell 1980;22:197-207.

29 Shimizu A, Tonjo T. Immunoglobulin class switching. Cell 1984;36:801-3.

30 Borzillo GV, Cooper MD, Kubagawa H, Landay A, Burrows PD. Isotype switching in human B lymphocyte malignancies occurs by DNA deletion: evidence for nonspecific switch recombination. F Immunol 1987;139:1326-35.

31 Rabbitts TH, Forster A, Milstein CP. Human immunoglobulin heavy chain genes: evolutionary com-
parisons of $\mathrm{C} \mu, \mathrm{C} \delta$ and $\mathrm{C} \gamma$ genes and associated switch parisons of $\mathrm{C} \mu, \mathrm{C} \delta$ and $\mathrm{C} \gamma$ genes and associa
sequences. Nucleic Acids Res 1981;9:4509-24.

32 Flanagan JG, Rabbitts TH. Arrangement of human immunoglobulin heavy chain constant region genes implie evolutionary duplication of a segment containing $\%, \varepsilon$ and $x$ genes. Nature 1982;300:709-13.

33 Ellison J, Hood L. Linkage and sequence homology of two human immunoglobulin $\gamma$ heavy chain constant region genes. Proc Natl Acad Sci USA 1982;79:1984-8. 